\title{
Germination of Indian Almond (Terminalia arjuna Roxb.) Seeds as Affected by Soil Salinity in Presence or Absence of Magnetic Iron Shahin, S. M. ${ }^{1}$; A. M. Aly ${ }^{1}$ and A. A. E. Helaly ${ }^{2}$ \\ ${ }^{1}$ Botanical Gards. Res. Dept., Hort. Res. Inst., ARC, Giza, Egypt \\ ${ }^{2}$ Vegt. \& Flori. Dept., Fac. Agric., Mansoura Univ., Egypt
}

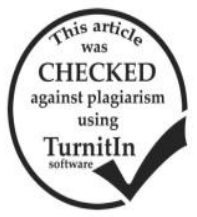

\section{ABSTRACT}

The hard seed coat is the major hindrance in achieving good and uniform germination for Indian almond (Terminalia arjuna Roxb.) fruits, especially when large plantations are to be raised under soil salinity stress. The present investigation was therefore, undertaken under the full sun at the nursery of Orman Botanical Garden, Giza during 2016 and 2017 seasons with the objective to find out the role of magnetic iron $\left(\mathrm{Fe}_{3} \mathrm{O}_{4}\right)$ on mitigating the hazards of $\mathrm{NaCl}$ salinity, when applied at the rates of 0 or $3 \mathrm{~g} / 20$-cmdimater plastic pot containing 10 fruits of arjuna and filled with about $3.5 \mathrm{~kg}$ of sand + clay mixture at equal parts $(1: 1, \mathrm{v} / \mathrm{v})$ salinized with $\mathrm{NaCl}$ pure salt at the concentrations of 0, 2000, 4000, 6000 and $8000 \mathrm{ppm}$. The effect of interactions between $\mathrm{Fe}_{3} \mathrm{O}_{4}$ application rates and salinity levels was also studied in a complete randomized design experiment with factorial concept replicated thrice. The obtained results indicated that means of germination percentage were descendingly decreased with increasing salinity level to reach less than $50 \%$ by 6000 and $8000 \mathrm{ppm}$ levels, while planting the fruits in a soil mixture free from salt gave the highest germination $\%$, followed by planting in 2000 ppm-salinized soil mixture, and then planting in soil mixture salinized with 4000 ppm concentration. On the other hand, addition of $\mathrm{Fe}_{3} \mathrm{O}_{4}(3 \mathrm{~g} / \mathrm{pot})$ significantly raised the mean of this measurement in both seasons. The shortest period to either maximum germination (G.V.) or $50 \%$ germination (MGR) was achieved in both seasons by planting in non salinized control and $2000 \mathrm{ppm}$-salinized media, whereas increasing salinity level over that (up to $8000 \mathrm{ppm}$ ) prolonged these periods with the greatest delay in germination. On the contrary, $\mathrm{Fe}_{3} \mathrm{O}_{4}$ significantly reduced the means of such two traits causing a marked accelerating in G.V. and MGR. A slight increment was noticed in the means of germination rate index (GRI) by the different salinity concentrations, while $\mathrm{Fe}_{3} \mathrm{O}_{4}$ caused a trivial decrement. A similar response occurred as well regarding the means of vigour index (V.I.), seed viability (S.V.), hypocotyl length and vegetative and root growth attributes of the resulted seedlings. So, it can be advised to apply magnetic iron $\left(\mathrm{Fe}_{3} \mathrm{O}_{4}\right)$ at the rate of $3 \mathrm{~g} /$ pot $(20$-cm-diameter) to improve germination and seedling quality of Terminalia arjuna Roxb. fruits planted in either low or medium salinized soil.

Keywords: Indian almond (Terminalia arjuna Roxb.), soil salinity, germination characters, magnetic iron $\left(\mathrm{Fe}_{3} \mathrm{O}_{4}\right)$.

\section{INTRODUCTION}

Indian almond (Terminalia arjuna Roxb.) is an evergreen forest tree, belonging to the Family Combretaceae, up to $25 \mathrm{~m}$ high with huge trunk. It is found in the tropical and sub-tropical parts of India and plays an important role in the sericulture industry (Orwa et al., 2009). It produces large orthodox seeds as propagules in a dark brown, 5-winged capsule. It is mainly used in the gardens as shade tree. It furnishes a good timber and its leaves form an ideal food for the Tasar silkworms (Dutta, 1995). Its white-to-pinkish-gray bark has been used in Indian's native medicine primarily as a cardiac tonic and also as a potent antioxidant for ischemic heart diseases (Sultana et al., 2007). It has antioxidant, anti-ischemic, antihypertensive and antihypertrophic effects, which have relevance to its therapeutic potential in cardiovascular diseases. Its efficacy, mostly in patients with ischemic heart disease, hypertension and heart failure, besides its potent antibacterial and antimutagenic activities were also reported (Kapoor, 1990; Bone, 1996; Maulik and Talwar, 2012). Naik et al. (2010) mentioned that bark of T. arjuna is the economic part, which contains arjunolic acid (arjunolitin).

Propagation of $T$. arjuna is difficult by seeds due to poor seed germination and seedling viability. Hence, cuttings and air-layering methods were adopted for this plant (Pandey et al., 2006). However, pre-sowing treatments with chemicals, growth hormones and irradiation were used for enhancing germination. In this regard, Naik et al. (2010) found that the propagation of $T$. arjuna through seeds can be practiced by treating the seeds first with concentrated sulphuric acid for 20 minutes and then pre-soaking for 18 hours in $\mathrm{GA}_{3}+\mathrm{BA}$ solution at $150 \mathrm{ppm}$. Furthermore, Akshatha et al. (2013) reported that germination speed of $T$. arjuna seeds irradiated with gamma ray at 25 Gy was found to be 0.65 , which was double compared to the unirradiated seeds. An increase in germination \%, vigour index and relative growth rate, in terms of dry weight was noticed at lower doses of the radiation treatment. The proline content increased with increasing doses. The chlorophyll content was increased to $12.2 \mathrm{mg} / \mathrm{g}$ f.w. at 100 Gy compared to control level of $8.4 \mathrm{mg} / \mathrm{g}$ f.w. Increased phenolic content and radical scavenging capacity was observed at 25 and 150 Gy.

On other Teminalia species, Hossain et al. (2005) revealed that depulping the fruits of $T$. chebula and soaking in water for various periods (12, 24 and $48 \mathrm{~h}$.) significantly enhanced seed germination and seedling growth. The highest germination percentage $(66.7 \%)$ was observed in the fruits depulped and soaked in cold water for $48 \mathrm{~h}$ (T4), followed by $60 \%$ in the depulped seeds soaked in cold water for $24 \mathrm{~h}$ (T3). The lowest germination \% (48.9\%) was obtained from controlled seeds (T0). The highest germination value (4.41), germination energy (58.9) and vigour index (5291) were also obtained in T4. Shoot length, root length, collar diameter and leaf number followed the same trend of higher value for $\mathrm{T} 4, \mathrm{~T} 5$ and $\mathrm{T} 3$, respectively (T5: depulped seeds and soaking in hot water for $2 \mathrm{~min}$.). Likewise, Michael et al. (2008) observed that nicking and soaking $T$. sericea seeds in cold water for $12 \mathrm{~h}$. gave the highest germination \% $(51 \%)$ for the first collection (when $60 \%$ of the fruits were deep-green to brown) and appears to be the most feasible and suitable pretreatment method for small scale farmers than use of $\mathrm{H}_{2} \mathrm{SO}_{4}$. Soaking in hot water for 15 and $20 \mathrm{~min}$. and immersion in concentrated $\mathrm{H}_{2} \mathrm{SO}_{4}$ for 3 and $4 \mathrm{~h}$. gave poorest germination percentage $(0 \%)$.

However, information in the literature about the germination and seedling growth of Terminalia spp under 
salt stress are very rare, except for Tomar and Gupta (1985) who mentioned that Acacia nilotica, Pongamia pinnata and Prosopis juliflora have been categorized as salinity tolerant tree species at the germination and seedling stages, while Terminalia arjuna has not been. In the areas where salinity is associated with high water table conditions, Tamarix, Prosopis and Casuarina species can be subsurface planted with success, while Acacia auriculiformis, A. nilotica and Terminalia arjuna can be grown in such areas if planted on the ridges. They also added that if salinity is associated with waterlogging, Terminalia arjuna can be grown up to a salinity of ECe = 7-10 mmhos/cm.

Overcoming the deleterious effects of salinity on germination and seedling growth through applying magnetic iron was studied before by Moustafa et al. (2017) who postulated that amending the soil texture with $2 \mathrm{~g} / \mathrm{pot}$ which contained 10 seeds of Moringa oleifera raised germination percentage to $100 \%$ for seeds sown in soil mixture salinized with $2000 \mathrm{ppm}$ of $\mathrm{NaCl}$ salt, while those sown in soil mixture salinized with 4000 and 8000 ppm $\mathrm{NaCl}$ salt, $\mathrm{Fe}_{3} \mathrm{O}_{4}$ rose their germination percentage to $50 \%$ or more. Magnetic iron accelerated germination speed when applied only to $2000 \mathrm{ppm}$ salinized soil mixture. The means of vigour index, seed viability, epicotyl length, seedling length, No. leaves/seedling, root length, No. roots/seedling, top growth and roots fresh and dry weights, as well as leaf contents of pigments, total soluble sugars and total indoles were greatly improved by applying of $\mathrm{Fe}_{3} \mathrm{O}_{4}$ (2g/pot) irrespective of salinity level. Similar observations were also reported by Abdel-Fattah (2014) on Jacaranda acutifolia and Ahmed et al. (2016) on Acalypha wilkesiana.
The current work aims to study the effect of magnetite on germination of arjuna seeds and on the first growth stages of the resulted seedlings when sown in a salinity affected soil.

\section{MATERIALS AND METHODS}

A pot experiment was carried out under the full sun at the nursery of Orman Botanical Garden, Giza, Egypt during the two consecutive seasons of 2016 and 2017 to detect the effects of different salinity concentrations on germination and seedling growth attributes of the hard seed-coated fruits of Indian almond tree (arjuna) and the role of magnetite on reducing the harmful effects of such salinity.

Therefore, mature fruits of Terminalia arjuna Roxb. known as arjuna and Indian almond, were collected from strong-build and healthy mother trees grown in Orman Botanical Garden on June, $1^{\text {st }}$ for each season. The fruits are 5-winged capsules, as each fruit contained only one seed (Das and Alam, 2001). All fruits were dried in sunlight and stored in a paper sac till the treatments were applied.

Uniform fruits (its long ranged between 2.9-3.1 $\mathrm{cm}$, diameter between $2.2-2.4 \mathrm{~cm}$ and weight between 2.0-2.2 g) were soaked in tap water for 48 hours on June, $20^{\text {th }}$ for every season as recommended by Gomaa (1998), then were sown in 20-cm-diameter plastic pots (10 fruits/pot) filled with about $3.5 \mathrm{~kg}$ of sand + clay soil mixture at equal parts by volume $(1: 1, \mathrm{v} / \mathrm{v})$ salinized with $\mathrm{NaCl}$ pure salt at the concentrations of 0,2000 , 4000, 6000 and 8000 ppm. The physical and chemical properties of the sand and clay used in the two seasons were determined and listed in Table (a).

Table a. The physical and chemical properties of the sand and clay used in 2016 and 2017 seasons

\begin{tabular}{|c|c|c|c|c|c|c|c|c|c|c|c|c|c|c|}
\hline \multirow{2}{*}{$\begin{array}{l}\text { Soil } \\
\text { type }\end{array}$} & \multicolumn{4}{|c|}{ Particle size distribution (\%): } & \multirow{2}{*}{ S.P. } & \multirow{2}{*}{$\begin{array}{c}\text { E.C. } \\
(\mathrm{dS} / \mathrm{m})\end{array}$} & \multirow{2}{*}{$\mathbf{p H}$} & \multicolumn{4}{|c|}{ Cations (meq/l) } & \multicolumn{3}{|c|}{ Anions (Meq/l) } \\
\hline & orco cand & & & & & & & & & & $\mathbf{K}^{+}$ & & $\mathrm{Cl}^{-}$ & \\
\hline & & & & & & & & & & & & & & \\
\hline Tayey & .64 & 22.50 & 0.15 & 39.71 & 52.38 & 2.33 & 3.10 & 7.50 & 2.21 & 15.49 & 0.75 & 6.78 & 8.02 & 11.15 \\
\hline
\end{tabular}

In addition, fruits sown in salinized soil mixture at the previously mentioned concentrations were drenched with magnetic iron $\left(\mathrm{Fe}_{3} \mathrm{O}_{4}, 22.5 \%\right)$, obtained from Alahram Mining Co., Giza at the rates of 0 or $3 \mathrm{~g} /$ pot. Each level of salinity was combined factorially with each one of the magnetic iron to create ten interaction treatments. A factorial in complete randomized design experiment with 3 replicates was adopted in both seasons, as each pot contained 10 seeds stands for one replicate (Mead et al., 1993). All agricultural practices necessary for seed care were done as usually grower did. The germination was recorded daily from date of sowing and continued till the germination ceased. The seed germination criterion was visible protrusion on the surface of soil at least $0.5 \mathrm{~cm}$ of the cotyledon and hypocotyle of the seedlings. Seedlings were then allowed to grow altogether under the same environmental conditions till end of the season (on October, $30^{\text {th }}$.), as the following data were recorded:

\section{A. Germination characteristics:}

1- Germination percentage (G \%) was calculated after completion of germination using the equation below:

G. $\%=$ No. germinated seeds/ Total No. sown seeds x 100 .
2- Germination velocity in days (G.V.), which equal average number of days from sowing till emergence of the final hypocotyle.

3- Mean germination rate in days (MGR) $=$ mean No. days till $50 \%$ germination (Odetola, 1987).

4- Germination rate index (GRI), which was calculated from Bartled equation indicated by Hartmann and Kester (1983):

$\mathbf{G R I}=\mathbf{A}+(\mathbf{A}+\mathbf{B})+(\mathbf{A}+\mathbf{B}+\mathbf{C})+\ldots / \mathbf{N}(\mathbf{A}+\mathbf{B}+\mathbf{C} . .)$.

Where: $A, B, C, \ldots$ etc: are No. germinated seeds counted at different times, and N: No. times at which the germinated seeds were counted.

5- Vigour index (VI) $=\mathrm{G} \% \mathrm{x}$ mean length of hypocotyle (Selvaraju and Selvaraj, 1994).

6- Seed viability $(\mathrm{SV})=$ No. survived seedlings in each treatment after excluding the deteriorated and dead ones (Odetola, 1987).

\section{B. Seedling growth parameters:}

Samples from the produced seedlings under each treatment were randomly selected and uprooted very carefully to estimate: seedling length $(\mathrm{cm})$, hypocotyle length $(\mathrm{cm})$, number of leaves/seedling, leaf area $\left(\mathrm{cm}^{2}\right)$, 
root length $(\mathrm{cm})$, as well as aerial parts and roots fresh and dry weights (g).

Data were then tabulated and subjected to analysis of variance using program of SAS Institute (2009), while the mean values were compared according to Duncan's New Multiple Range Test at $5 \%$ level of probability (Steele and Torrie, 1980).

\section{RESULTS AND DISCUSSION}

\section{- Effect of salinity level, magnetite application and their interactions on: \\ 1- Germination characters and hypocotyle length:}

Data presented in Table (1a) exhibit that means of germination percentage were gradually decreased with increasing $\mathrm{NaCl}$ salt concentration to be less than $50 \%$ by 6000 and 8000 ppm levels in the two seasons, while 4000 ppm level gave germination percent slightly more than 50 $\%\left(5288 \%\right.$ in the $1^{\text {st }}$ season and $56.87 \%$ in the $2^{\text {nd }}$ one $)$. However the highest records were attained in both seasons by sowing in a soil mixture free from salts (control), followed by sowing in $2000 \mathrm{ppm}$-salinized soil mixture.

The reduction in germination \% by high salt levels may be due to that excess of soluble salts causes a reduction in soil-water potential leading to less water availability to be absorbed by seeds. This water potential reduction and the toxic effect of salt interfere with water absorption process influencing germination (Fahey, 2005). The salt may cause changes in functions of the cell membranes and the cell walls, and may affect the water potential of the cytosol and cellular extensibility, and consequently may affect seed germination and seedling growth (Santos et al., 2011). Moreover, Lobato et al.
(2009) suggested that the progressive decrease in the available water under salt stress may interfere in hydrolytic enzymes activity affecting the supplement and velocity of water assimilation. In this regard, Tomar and Gupta (1985) stated that Terminalia arjuna can tolerate salinity of ECe ranged between $7-10 \mathrm{mmhos} / \mathrm{cm}$ (4000-6000 ppm) if salinity was associated with high water table conditions. However, the seedlings are not able to tolerate these levels like the mature plants.

On the other side, germination percentage was slightly higher than $40 \%$ for fruits planted in the soil mixture not treated with $\mathrm{Fe}_{3} \mathrm{O}_{4}$, while adding it at $3 \mathrm{~g} /$ pot significantly raised the mean of germination to more than $60 \%$ in both seasons. However, the greatest percent of germination was attained in the two seasons by planting the fruits in soil mixture free from salinity and amended with $3 \mathrm{~g} /$ pot magnetic iron, as this combination elevated means of such trait to 93.89 and $96.45 \%$ in the first and second seasons, respectively, and followed by 78.83 and $83.25 \%$ for the two seasons by the combination of planting in $2000 \mathrm{ppm}$-salinized soil mixture $+3 \mathrm{~g} /$ pot $\mathrm{Fe}_{3} \mathrm{O}_{4}$. Magnetic applying caused also a significant increment in germination \% for fruits sown in $4000 \mathrm{ppm}$ salinized soil mixture from 50 to $55.76 \%$ in the $1^{\text {st }}$ season and from 54.33 to $59.40 \%$ in the second one. This may indicate the role of magnetic iron in reducing soil salinity through decreasing the hydration of salt ions and colloids, having a positive effect on salt solubility and finally leading to leaching of the salts. Thus, it is successfully used to reclaim soils with high cations and anions, such as $\mathrm{Ca}$, $\mathrm{Na}, \mathrm{Cl}$ and $\mathrm{HCO}_{3}$ (Mostafazadeh et al., 2012).

Table 1a. Effect of salinity level, magnetite application and their interactions on some germination traits of Terminalia arjuna Roxb. seeds during 2016 and 2017 seasons

\begin{tabular}{|c|c|c|c|c|c|c|c|c|c|c|c|c|}
\hline \multirow{2}{*}{$\begin{array}{l}\text { Magnetite } \\
\text { (3 g/pot) } \\
\text { Salinity level (ppm) }\end{array}$} & \multicolumn{3}{|c|}{$\begin{array}{c}\text { Germination } \\
(\%)\end{array}$} & \multicolumn{3}{|c|}{$\begin{array}{c}\text { Germination velocity } \\
\text { (day) }\end{array}$} & \multicolumn{3}{|c|}{$\begin{array}{l}\text { Mean germination rate } \\
\text { (MGR) (day) }\end{array}$} & \multicolumn{3}{|c|}{$\begin{array}{l}\text { Germination rate } \\
\text { index (GRI) }\end{array}$} \\
\hline & $\mathbf{0}$ & 3 & Mean & $\mathbf{0}$ & 3 & Mean & $\mathbf{0}$ & 3 & Mean & $\mathbf{0}$ & 3 & Mean \\
\hline & \multicolumn{12}{|c|}{ First season: 2016} \\
\hline 0 & $67.50 \mathrm{c}$ & $93.89 \mathrm{a}$ & $80.70 \mathrm{a}$ & $28.80 \mathrm{f}$ & $31.67 \mathrm{e}$ & $30.24 \mathrm{c}$ & $28.00 \mathrm{~d}$ & $30.33 \mathrm{~d}$ & & $0.60 \mathrm{~b}$ & $0.63 b$ & $0.62 \mathrm{a}$ \\
\hline 2000 & $.65 d$ & $78.83 b$ & $67.24 b$ & $30.00 \mathrm{e}$ & $32.38 \mathrm{e}$ & $31.19 \mathrm{c}$ & $33.76 \mathrm{c}$ & $26.50 \mathrm{~d}$ & $13 b$ & $0.67 \mathrm{ab}$ & $0.63 b$ & $0.65 \mathrm{a}$ \\
\hline 4000 & $.00 \mathrm{e}$ & $55.76 \mathrm{~d}$ & $52.88 \mathrm{c}$ & $56.50 \mathrm{~b}$ & $41.71 \mathrm{~d}$ & $49.11 \mathrm{~b}$ & $56.50 \mathrm{a}$ & $43.50 \mathrm{~b}$ & $50.00 \mathrm{a}$ & $0.75 \mathrm{a}$ & $0.63 b$ & $0.69 \mathrm{a}$ \\
\hline 6000 & $30.50 \mathrm{~g}$ & $40.33 \mathrm{f}$ & $35.42 d$ & $63.72 \mathrm{a}$ & $47.25 \mathrm{~cd}$ & $55.49 \mathrm{a}$ & - & - & - & $0.76 \mathrm{a}$ & $0.65 b$ & $0.71 \mathrm{a}$ \\
\hline 8000 & 00 & $33.35 \mathrm{~g}$ & $16.68 \mathrm{e}$ & - & $50.33 \mathrm{c}$ & $50.33 b$ & - & - & - & - & $0.68 \mathrm{ab}$ & $0.68 \mathrm{a}$ \\
\hline \multirow[t]{2}{*}{ Mean } & $40.73 b$ & $60.43 a$ & & $44.75 \mathrm{a}$ & $40.67 \mathrm{~b}$ & & $39.42 \mathrm{a}$ & $33.44 \mathrm{~b}$ & & $0.70 \mathrm{a}$ & $0.65 \mathrm{a}$ & \\
\hline & \multicolumn{12}{|c|}{ Second season: 2017} \\
\hline 0 & $58.00 \mathrm{~cd}$ & $96.45 \mathrm{a}$ & $77.23 \mathrm{a}$ & $31.83 \mathrm{f}$ & $32.60 \mathrm{e}$ & $32.22 \mathrm{c}$ & $31.00 \mathrm{~d}$ & $31.00 \mathrm{~d}$ & & $0.63 b$ & $0.65 b$ & $0.64 \mathrm{a}$ \\
\hline 2000 & $60.12 \mathrm{c}$ & $83.25 b$ & $71.69 b$ & $33.50 \mathrm{e}$ & $34.85 \mathrm{e}$ & $34.18 \mathrm{c}$ & $37.16 \mathrm{c}$ & $29.75 d$ & $33.46 \mathrm{~b}$ & $0.70 \mathrm{ab}$ & $0.65 b$ & $0.68 \mathrm{a}$ \\
\hline 4000 & $54.33 \mathrm{~d}$ & $59.40 \mathrm{c}$ & $56.87 \mathrm{c}$ & $57.11 \mathrm{~b}$ & $45.04 d$ & $51.08 \mathrm{~b}$ & $55.50 \mathrm{a}$ & $46.35 b$ & $50.93 \mathrm{a}$ & $0.75 a$ & $0.67 \mathrm{~b}$ & $0.71 \mathrm{a}$ \\
\hline 6000 & $32.41 \mathrm{f}$ & $43.21 \mathrm{e}$ & $37.81 \mathrm{~d}$ & $67.48 \mathrm{a}$ & $50.50 \mathrm{c}$ & $58.99 \mathrm{a}$ & - & - & - & $0.77 \mathrm{a}$ & $0.67 b$ & $0.72 \mathrm{a}$ \\
\hline 8000 & 0.00 & $33.31 \mathrm{f}$ & $16.66 \mathrm{e}$ & - & $56.33 b$ & $56.33 a$ & - & - & - & - & $0.69 \mathrm{ab}$ & $0.69 \mathrm{a}$ \\
\hline Mean & $40.97 b$ & $63.13 \mathrm{a}$ & & $47.48 \mathrm{a}$ & $43.87 \mathrm{~b}$ & & $41.22 \mathrm{a}$ & $35.70 \mathrm{~b}$ & & $0.71 \mathrm{a}$ & $0.67 \mathrm{a}$ & \\
\hline
\end{tabular}

Means followed by the same latter in a column or row do not differ significantly according to Duncan's New Multiple Range Test at $5 \%$ level.

The shortest period to either maximum germination (G.V.) or $50 \%$ germination (MGR) was recorded in the two seasons by control and $2000 \mathrm{ppm}$ salinity treatments, as these two treatments registered the least No. days to such two criteria with nonsignificant differences in between. Increasing salinity level to $4000 \mathrm{ppm}$ significantly prolonged the periods of these two characters in both seasons, and that was true also for 6000 and 8000 ppm levels which induced the greatest delay in G.V., and failed to increase germination to $50 \%$ or more. On the contrary, magnetic iron significantly reduced means of these two traits in both seasons inducing a marked accelerating in G.V. and MGR. A slight increment was observed in the means of germination rate index (GRI) by the different salinity concentrations, but tenuously decreased by application of $\mathrm{Fe}_{3} \mathrm{O}_{4}$ with non-significant differences compared to control in the two seasons. 
In addition, data presented in Table (1b) clear that means of vigour index, seed viability and hypocotyl length $(\mathrm{cm})$ were progressively diminished as the salinity concentration was increased with significant differences relative to means of control in most cases of both seasons.
This may be ascribed to the hazards of salinity on germination attributes. The opposite was the right regarding the effect of $\mathrm{Fe}_{3} \mathrm{O}_{4}$ application that caused a significant improvement in these characters over control in the two seasons regardless of salinity level.

Table 1b. Effect of salinity level, magnetite application and their interactions on some germination traits of Terminalia arjuna Roxb. seeds during 2016 and 2017 seasons

\begin{tabular}{|c|c|c|c|c|c|c|c|c|c|}
\hline \multirow{2}{*}{$\begin{array}{l}\text { Magnetite (g/pot) } \\
\text { Salinity level (ppm) }\end{array}$} & \multicolumn{3}{|c|}{ Vigour index (VI) } & \multicolumn{3}{|c|}{ Seed viability (SV) } & \multicolumn{3}{|c|}{ Hypocotyle length $(\mathrm{cm})$} \\
\hline & $\mathbf{0}$ & 3 & Mean & $\mathbf{0}$ & 3 & Mean & $\mathbf{0}$ & 3 & Mean \\
\hline & \multicolumn{9}{|c|}{ First season: 2016} \\
\hline 0 & $67.50 \mathrm{c}$ & $138.96 \mathrm{a}$ & $103.23 \mathrm{a}$ & $4.00 \mathrm{~b}$ & $8.33 \mathrm{a}$ & $6.17 \mathrm{a}$ & $1.00 \mathrm{~b}$ & $1.48 \mathrm{a}$ & $1.24 \mathrm{a}$ \\
\hline 2000 & $52.20 \mathrm{~d}$ & $99.33 b$ & $75.27 \mathrm{~b}$ & $1.76 \mathrm{c}$ & $3.50 \mathrm{~b}$ & $2.63 \mathrm{~b}$ & $0.92 b$ & $1.25 \mathrm{ab}$ & $1.09 \mathrm{ab}$ \\
\hline 4000 & $42.00 \mathrm{e}$ & $52.97 \mathrm{~d}$ & $47.49 \mathrm{c}$ & $0.00 \mathrm{~d}$ & $2.00 \mathrm{c}$ & $1.00 \mathrm{c}$ & $0.84 \mathrm{~b}$ & $0.95 \mathrm{~b}$ & $0.90 \mathrm{~b}$ \\
\hline 6000 & $17.69 \mathrm{~h}$ & $33.48 \mathrm{f}$ & $25.59 d$ & $0.00 \mathrm{~d}$ & $1.10 \mathrm{c}$ & $0.55 \mathrm{c}$ & $0.58 \mathrm{c}$ & $0.83 \mathrm{~b}$ & $0.71 \mathrm{~b}$ \\
\hline 8000 & - & $26.01 \mathrm{~g}$ & $26.01 \mathrm{~d}$ & - & $0.00 \mathrm{~d}$ & $0.00 \mathrm{~d}$ & - & $0.78 \mathrm{bc}$ & $0.78 b$ \\
\hline \multirow[t]{2}{*}{ Mean } & $44.60 \mathrm{~b}$ & $70.15 \mathrm{a}$ & & $1.44 \mathrm{~b}$ & $3.73 \mathrm{a}$ & & $0.84 \mathrm{~b}$ & $1.06 \mathrm{a}$ & \\
\hline & \multicolumn{9}{|c|}{ Second season: 2017} \\
\hline 0 & $54.2 \mathrm{c}$ & $136.00 \mathrm{a}$ & $95.26 \mathrm{a}$ & $4.33 b$ & $9.00 \mathrm{a}$ & $6.67 \mathrm{a}$ & $0.94 \mathrm{~b}$ & $1.41 \mathrm{a}$ & $1.18 \mathrm{a}$ \\
\hline 2000 & $54.11 \mathrm{c}$ & $104.06 \mathrm{~b}$ & $49.09 \mathrm{~b}$ & $1.91 \mathrm{c}$ & $3.76 \mathrm{~b}$ & $2.84 \mathrm{~b}$ & $0.90 \mathrm{~b}$ & $1.25 \mathrm{ab}$ & $1.08 \mathrm{ab}$ \\
\hline 4000 & $44.01 \mathrm{~d}$ & $55.24 \mathrm{c}$ & $49.63 \mathrm{c}$ & $0.00 \mathrm{~d}$ & $2.15 \mathrm{c}$ & $1.08 \mathrm{c}$ & $0.81 \mathrm{~b}$ & $0.93 b$ & $0.87 \mathrm{~b}$ \\
\hline 6000 & $19.45 \mathrm{f}$ & $33.71 \mathrm{e}$ & $26.58 \mathrm{~d}$ & $0.00 \mathrm{~d}$ & $1.17 \mathrm{c}$ & $0.59 \mathrm{c}$ & $0.60 \mathrm{c}$ & $0.78 b c$ & $0.69 \mathrm{~b}$ \\
\hline 8000 & - & $22.32 \mathrm{f}$ & $22.32 d$ & - & $0.00 \mathrm{~d}$ & $0.00 \mathrm{~d}$ & - & $0.67 b c$ & $0.67 b$ \\
\hline Mean & $43.02 \mathrm{~b}$ & $70.27 \mathrm{a}$ & & $1.56 \mathrm{~b}$ & $4.02 \mathrm{a}$ & & $0.81 \mathrm{~b}$ & $1.01 \mathrm{a}$ & \\
\hline
\end{tabular}

Means followed by the same latter in a column or row do not differ significantly according to Duncan's New Multiple Range Test at $5 \%$ level.

2- Vegetative and root growth parameters of the resulted seedlings:

A similar trend to that of germination characteristics was also obtained concerning vegetative and root growth parameters of the resulted seedlings, where data averaged in Tables ( 2 and 3 ) showed that the means of seedling length $(\mathrm{cm})$, hypocotyle length $(\mathrm{cm})$, No. leaves/seedling, leaf area $\left(\mathrm{cm}^{2}\right)$, root length $(\mathrm{cm})$, as well as aerial parts and roots fresh and dry weights $(\mathrm{g})$ were descendingly decreased in response to the progressive increment of salinity concentrations to reach the minimal values by 6000 and 8000 ppm levels comparing with control in the first and second seasons. This deleterious effect of salinity may be attributed to the lower rate of cell division and ethylene production in seedlings subjected to this type of stress. This hormone is a consequence for decreasing of seedling size (Lobato et al., 2009). Further, Allen (1995) affirmed that the decrease in biomass production of many plants under salt stress is mainly referred to generation of reactive oxygen species (ROS) in chloroplast, which diminishes the plant growth in the absence of any protective system like antioxidant system. In this concern, Moustafa et al. (2017) on Moringa, concluded that a gradual decrement was observed in the means of seedling length, No. leaves/seedling, root length, No. roots / seedling, as well as top growth and roots fresh and dry weights with the gradual increment in salinity level up to $4000 \mathrm{ppm}$.

Table 2. Effect of salinity level, magnetite application and their interactions on growth traits of Terminalia arjuna Roxb. seeds during 2016 and 2017 seasons

\begin{tabular}{|c|c|c|c|c|c|c|c|c|c|c|c|c|c|c|c|}
\hline \multirow{2}{*}{$\begin{array}{l}\text { Magnetite } \\
\text { (g/pot) } \\
\text { Salinity } \\
\text { level (ppm) }\end{array}$} & \multicolumn{3}{|c|}{$\begin{array}{c}\text { Seedling length } \\
(\mathrm{cm})\end{array}$} & \multicolumn{3}{|c|}{$\begin{array}{c}\text { Hypocotyle length } \\
(\mathrm{cm})\end{array}$} & \multicolumn{3}{|c|}{$\begin{array}{c}\text { No. leaves/ } \\
\text { seedling }\end{array}$} & \multicolumn{3}{|c|}{$\begin{array}{c}\text { Leaf area } \\
\left(\mathrm{cm}^{2}\right)\end{array}$} & \multicolumn{3}{|c|}{$\begin{array}{c}\text { Root length } \\
(\mathrm{cm})\end{array}$} \\
\hline & $\mathbf{0}$ & 3 & Mean & $\mathbf{0}$ & 3 & Mean & $\mathbf{0}$ & 3 & Mean & $\mathbf{0}$ & 3 & Mean & $\mathbf{0}$ & 3 & Mean \\
\hline & \multicolumn{15}{|c|}{ First season: 2016} \\
\hline 0 & $52.50 \mathrm{a}$ & $55.20 \mathrm{a}$ & $53.85 a$ & $5.6 \mathrm{ab}$ & $6.00 \mathrm{a}$ & $5.8 \mathrm{a}$ & $22.00 \mathrm{~b}$ & $24.00 \mathrm{a}$ & $23.0 \mathrm{a}$ & $25.1 \mathrm{a}$ & $25.5 \mathrm{a}$ & & $28.7 b$ & $32.6 a$ & $30.7 \mathrm{a}$ \\
\hline 2000 & $37.10 \mathrm{bc}$ & $41.23 b$ & $39.17 b$ & $4.5 b$ & $4.8 b$ & $4.7 b$ & $18.00 \mathrm{c}$ & $22.00 \mathrm{~b}$ & $20.0 \mathrm{~b}$ & $24.5 \mathrm{a}$ & $25.3 \mathrm{a}$ & $24.9 \mathrm{a}$ & $22.4 \mathrm{c}$ & $27.0 \mathrm{~b}$ & $24.7 b$ \\
\hline 4000 & $29.50 \mathrm{~cd}$ & $32.99 \mathrm{c}$ & $31.25 \mathrm{c}$ & $3.6 \mathrm{c}$ & $3.8 \mathrm{c}$ & $3.7 \mathrm{c}$ & $15.33 d$ & $17.67 \mathrm{c}$ & $16.50 \mathrm{c}$ & $21.5 b$ & $24.5 \mathrm{a}$ & $23.0 \mathrm{~b}$ & $17.3 \mathrm{~d}$ & $21.5 \mathrm{c}$ & $19.4 \mathrm{c}$ \\
\hline 6000 & $18.52 \mathrm{de}$ & $24.40 d$ & $21.46 \mathrm{~d}$ & $2.9 \mathrm{~d}$ & $3.1 \mathrm{~d}$ & $3.0 \mathrm{~d}$ & $9.67 \mathrm{f}$ & $12.26 \mathrm{e}$ & $11.0 \mathrm{~d}$ & $17.3 \mathrm{c}$ & $18.5 b c$ & $17.9 \mathrm{c}$ & $13.8 \mathrm{e}$ & 15.9de & $14.9 \mathrm{~d}$ \\
\hline 8000 & - & $13.50 \mathrm{e}$ & $13.50 \mathrm{e}$ & - & $3.0 \mathrm{~d}$ & $3.0 \mathrm{~d}$ & - & $5.33 \mathrm{~g}$ & $5.3 e$ & - & $8.2 \mathrm{~d}$ & $8.2 \mathrm{~d}$ & - & $12.3 \mathrm{e}$ & $12.3 \mathrm{~d}$ \\
\hline Mean & $34.41 \mathrm{a}$ & $33.47 \mathrm{a}$ & & $4.15 \mathrm{a}$ & $4.14 a$ & & $16.25 \mathrm{a}$ & $16.25 \mathrm{a}$ & & $22.1 \mathrm{a}$ & $20.4 b$ & & $20.6 \mathrm{~b}$ & $21.9 \mathrm{a}$ & \\
\hline & \multicolumn{15}{|c|}{ Second season: 2017} \\
\hline 0 & $55.10 \mathrm{a}$ & $58.76 a$ & $56.93 a$ & $5.9 \mathrm{~b}$ & $6.5 a$ & $6.20 \mathrm{a}$ & $23.10 \mathrm{~b}$ & $26.10 \mathrm{a}$ & $24.60 \mathrm{a}$ & $26.3 \mathrm{a}$ & $27.0 \mathrm{a}$ & $26.7 \mathrm{a}$ & $26.5 b$ & $33.5 \mathrm{a}$ & $30.0 \mathrm{a}$ \\
\hline 2000 & $38.96 b c$ & $43.58 b$ & $41.27 b$ & $4.7 \mathrm{~cd}$ & $5.1 \mathrm{c}$ & $4.9 b$ & $19.00 \mathrm{c}$ & $23.00 \mathrm{~b}$ & $21.00 \mathrm{~b}$ & $25.7 \mathrm{a}$ & $26.6 \mathrm{a}$ & $26.2 \mathrm{a}$ & $23.1 \mathrm{c}$ & $28.4 b$ & $25.8 b$ \\
\hline 4000 & $30.41 \mathrm{~cd}$ & $34.00 \mathrm{c}$ & $32.21 \mathrm{c}$ & $3.8 \mathrm{de}$ & $4.1 d$ & $4.0 \mathrm{c}$ & $16.10 \mathrm{~d}$ & $18.60 \mathrm{c}$ & $17.35 \mathrm{c}$ & $21.3 b$ & $25.5 \mathrm{a}$ & $23.4 b$ & $17.8 \mathrm{~d}$ & $22.0 \mathrm{c}$ & $19.9 \mathrm{c}$ \\
\hline 6000 & $19.43 \mathrm{de}$ & $25.50 \mathrm{~d}$ & $22.47 \mathrm{~d}$ & $3.0 \mathrm{e}$ & $3.3 \mathrm{e}$ & $3.2 \mathrm{~d}$ & $9.50 \mathrm{f}$ & $13.00 \mathrm{e}$ & $11.25 \mathrm{~d}$ & $16.9 \mathrm{c}$ & $18.2 b c$ & $17.6 \mathrm{c}$ & $14.6 \mathrm{de}$ & $16.8 \mathrm{~d}$ & $15.7 d$ \\
\hline 8000 & - & $13.97 \mathrm{e}$ & $13.97 \mathrm{e}$ & - & $3.0 \mathrm{e}$ & $3.0 \mathrm{~d}$ & - & $6.00 \mathrm{~g}$ & $6.00 \mathrm{e}$ & - & $9.1 d$ & $9.1 \mathrm{~d}$ & - & $13.1 \mathrm{e}$ & $13.1 \mathrm{e}$ \\
\hline Mean & $35.99 \mathrm{a}$ & $35.16 \mathrm{a}$ & & $4.40 \mathrm{a}$ & $4.4 \mathrm{a}$ & & $16.93 \mathrm{a}$ & $17.34 \mathrm{a}$ & & $22.6 \mathrm{a}$ & $21.3 \mathrm{~b}$ & & $20.5 b$ & $22.8 \mathrm{a}$ & \\
\hline
\end{tabular}

Means followed by the same latter in a column or row do not differ significantly according to Duncan's New Multiple Range Test at $5 \%$ level. 
On the other hand, amending the soil mixture with $3 \mathrm{~g} /$ pot of $\mathrm{Fe}_{3} \mathrm{O}_{4}$ markedly improved all the aforementioned growth parameters under the various salinity levels. This may explain the role of magnetic iron in mitigating the harmful effects of salinity through creating an electromagnetic field which helps the passage of useful nutrients to the roots of plants plus shocks nematodes and microbes on the roots, improving the water balance of the soil, increasing root growth, rising salts washing efficiency in the soil, and finally separating chlorine, natrium and toxic gasses magnetically from the soil (Mostafazadeh et al., 2012).

The interaction between the used two factors indicated that combining between salinity at any level and applying of magnetic iron caused noticeable improvements in the abovenemed growth traits, especially at the low levels of salinity. These gains can be supported by those revealed by Santos (2011) and Moustafa et al. (2017) on Moringa oleifera, AbdelFattah (2014) on Jacaranda acutifolia and Ahmed et al. (2016) on Acalypha wilkesiana.

Hence, the results of this experiment enable us to use magnetic field for alleviating the determinatal effects of salinity on germination of Terminalia arjuna seeds and the initial growth performance of the produced seedlings.

Table 3. Effect of salinity level, magnetite application and their interactions on aerial parts and roots fresh and dry weights of Terminalia arjuna Roxb. seedlings during 2016 and 2017 seasons

\begin{tabular}{|c|c|c|c|c|c|c|c|c|c|c|c|c|}
\hline \multirow{3}{*}{$\begin{array}{l}\text { Magnetite (g/pot) } \\
\text { Salinity level } \\
\text { (ppm) }\end{array}$} & \multicolumn{6}{|c|}{ Aerial parts } & \multicolumn{6}{|c|}{ Roots } \\
\hline & \multicolumn{3}{|c|}{ Fresh weight (g) } & \multicolumn{3}{|c|}{ Dry weight (g) } & \multicolumn{3}{|c|}{ Fresh weight (g) } & \multicolumn{3}{|c|}{ Dry weight (g) } \\
\hline & $\mathbf{0}$ & 3 & Mean & $\mathbf{0}$ & 3 & Mean & $\mathbf{0}$ & 3 & Mean & $\mathbf{0}$ & 3 & Mean \\
\hline & \multicolumn{12}{|c|}{ First season: 2016} \\
\hline 0 & $11.55 \mathrm{ab}$ & $12.69 \mathrm{a}$ & $12.12 \mathrm{a}$ & $2.91 \mathrm{ab}$ & $3.17 \mathrm{a}$ & $3.04 \mathrm{a}$ & $2.63 \mathrm{~cd}$ & $4.85 \mathrm{a}$ & $3.74 \mathrm{a}$ & $1.15 \mathrm{~cd}$ & $2.18 \mathrm{a}$ & $1.67 \mathrm{a}$ \\
\hline 2000 & $8.71 \mathrm{~b}$ & $11.50 \mathrm{ab}$ & $10.11 \mathrm{~b}$ & $2.18 \mathrm{~b}$ & $2.90 \mathrm{ab}$ & $2.54 \mathrm{~b}$ & $2.38 \mathrm{~d}$ & $4.02 \mathrm{~b}$ & $3.20 \mathrm{ab}$ & $1.07 \mathrm{~d}$ & $1.83 \mathrm{~b}$ & $1.45 \mathrm{~b}$ \\
\hline 4000 & $6.89 \mathrm{c}$ & $9.28 \mathrm{~b}$ & $8.09 \mathrm{c}$ & $1.73 \mathrm{c}$ & $2.33 \mathrm{~b}$ & $2.03 \mathrm{c}$ & $1.91 \mathrm{de}$ & $3.18 \mathrm{c}$ & $2.55 \mathrm{c}$ & $0.86 \mathrm{de}$ & $1.42 \mathrm{c}$ & $1.14 \mathrm{~b}$ \\
\hline 6000 & $5.13 \mathrm{~d}$ & $6.42 \mathrm{c}$ & $5.78 \mathrm{~d}$ & $1.30 \mathrm{~d}$ & $1.58 \mathrm{c}$ & $1.44 \mathrm{~d}$ & $1.27 \mathrm{e}$ & $2.31 \mathrm{~d}$ & $1.79 \mathrm{~d}$ & $0.55 \mathrm{e}$ & $1.03 \mathrm{~d}$ & $0.79 \mathrm{bc}$ \\
\hline 8000 & - & $1.86 \mathrm{e}$ & $1.86 \mathrm{e}$ & - & $0.43 \mathrm{e}$ & $0.43 \mathrm{e}$ & - & $1.39 \mathrm{e}$ & $1.39 \mathrm{~d}$ & - & $0.57 \mathrm{e}$ & $0.57 \mathrm{c}$ \\
\hline Mean & $8.07 \mathrm{a}$ & $8.35 \mathrm{a}$ & & $2.03 \mathrm{a}$ & $2.08 \mathrm{a}$ & & $2.05 \mathrm{~b}$ & $3.15 \mathrm{a}$ & & $0.91 \mathrm{~b}$ & $1.41 \mathrm{a}$ & \\
\hline \multicolumn{13}{|c|}{ Second season: 2017} \\
\hline 0 & $12.41 \mathrm{ab}$ & $13.71 \mathrm{a}$ & $13.06 \mathrm{a}$ & $3.12 \mathrm{ab}$ & $3.45 \mathrm{a}$ & $3.29 \mathrm{a}$ & $2.81 \mathrm{~cd}$ & $5.26 \mathrm{a}$ & $4.04 \mathrm{a}$ & $1.20 \mathrm{~cd}$ & $2.38 \mathrm{a}$ & $1.79 \mathrm{a}$ \\
\hline 2000 & $9.50 \mathrm{~b}$ & $12.33 \mathrm{ab}$ & $10.92 b$ & $2.36 \mathrm{~b}$ & $3.13 \mathrm{ab}$ & $2.75 b$ & $2.57 \mathrm{~d}$ & $4.33 b$ & $3.45 \mathrm{~b}$ & $1.10 \mathrm{~d}$ & $1.97 \mathrm{~b}$ & $1.54 \mathrm{ab}$ \\
\hline 4000 & $7.45 c$ & $10.00 \mathrm{~b}$ & $8.73 c$ & $1.87 \mathrm{c}$ & $2.50 \mathrm{~b}$ & $2.19 \mathrm{c}$ & $2.05 \mathrm{de}$ & $3.41 \mathrm{c}$ & $2.73 \mathrm{c}$ & $0.92 \mathrm{de}$ & $1.51 \mathrm{c}$ & $1.22 \mathrm{~b}$ \\
\hline 6000 & $5.54 \mathrm{~d}$ & $6.93 \mathrm{c}$ & $6.24 d$ & $1.39 \mathrm{~d}$ & $1.71 \mathrm{c}$ & $1.55 \mathrm{~d}$ & $1.40 \mathrm{e}$ & $2.50 \mathrm{~d}$ & $1.95 \mathrm{~d}$ & $0.60 \mathrm{e}$ & $1.12 \mathrm{~d}$ & $0.86 \mathrm{bc}$ \\
\hline 8000 & - & $2.01 \mathrm{e}$ & $2.01 \mathrm{e}$ & - & $0.75 \mathrm{~d}$ & $0.75 \mathrm{e}$ & - & $1.43 \mathrm{e}$ & $1.43 \mathrm{~d}$ & - & $0.60 \mathrm{e}$ & $0.60 \mathrm{c}$ \\
\hline Mean & $8.73 \mathrm{a}$ & $9.00 \mathrm{a}$ & & $2.19 a$ & $2.31 \mathrm{a}$ & & $2.21 \mathrm{~b}$ & $3.39 \mathrm{a}$ & & $0.96 \mathrm{~b}$ & $1.52 \mathrm{a}$ & \\
\hline
\end{tabular}

Means followed by the same latter in a column or row do not differ significantly according to Duncan's New Multiple Range Test at $5 \%$ level.

\section{REFERENCES}

Abdel-Fattah, Gehan, H. (2014). The role of magnetic iron and sodium selenate in minimizing soil salt hazards on growth and quality of Jacaranda acutifolia Humb. \& Bonpl. seedlings. Sci. J. Flowers \& Ornam. Plants, 1 (3): 187-198.

Ahmed, Magda A.; Abdel-Fattah, Gehan H. and Shahin, S. M. (2016). The role of magnetic iron in enhancing the ability of Acalypha wilkesiana Müll. Arg. transplants to tolerate soil salinity. J. Plant Production, Mansoura Univ., 7 (3): 379-384.

Akshatha, K.; Chandrashekar, R.; Somashekarappa, H.M. and Souframanien, J. (2013). Effect of gamma irradiation on germination, growth and biochemical parameters of Terminalia arjuna Roxb. Radiation Protection and Environment, 36 (1): $38-44$.

Allen, R. (1995). Dissection of oxidative stress tolerance using transgenic plants. Plant Physiol., 107: 1049-1054.

Bone, K. (1996). Chemical Application of Ayurvedic and Chinese Herbs. Monographs for the western herbal practitioner Warwick. Queens L., Australia, Phototherapy press.
Das, D. K. and Alam, M. K. (2001). Trees of Bangladesh. Bangladesh Forest Research Institute, Chittagong, Bangladesh, 324 pp.

Dutta, R. K. (1995). An overview of research in sericulture biotechnology. Proc. National Academy of Sciences, 65: 203-216.

Fahey, J. W. (2005). Moringa oliefera: A review of the medical evidence for its nutritional, therapeutic and prophylactic properties. Trees for life J., 1 (1):5.

Gomaa, Eman, E. (1998). Studies on propagation of some ornamental trees. M. Sc. Thesis, Fac. Agric., Kafr El-Sheikh, Tanta Univ.

Hartmann, H. T. and Kester, D. F. (1983). Plant Propagation: Principles and Practices. PrenticeHall Inc., Inglewood Cliffs, N. J., 662pp.

Hossain, M. A.; Arefin, M. K.; Khan, B. M. and Rahman, M. A. (2005). Effects of seed treatments on germination and seedling growth attributes of Horitaki (Terminalia chebula Retz.) in the nursery. Res. J. Agric. and Bio. Sci., 1 (2): 135141.

Kapoor, L. D. (1990). Handbook of Ayurvedic Medicinal Plants. Boca Raton, FL:CRC Press, Florida, 424 pp. 
Lobato, A. K.; Santos, F. B.; Costa, R. C.; Goncalves, M. C.; Mores, E. C.; Oliveira, C. F.; Rodrigues, V. L.; Cruz, F. J.; Pita, J. D. and Barreto, A. G. (2009). Morphological, physiological and biochemical responses during germination of Vigna unguiculata cv. Pitiuba seeds under salt stress. Agricultural Sciences, 5 (5): 590-596.

Maulik, S. K. and Talwar, K. K. (2012). Therapeutic potential of Terminalia arjuna in cardiovascular disorders. Amer. J. Cardiovasc Drugs, 12: 157163.

Mead, R.; Curnow, R. N. and Harted, A. M. (1993). Statistical Methods in Agriculture and Experimental Biology. $2^{\text {nd }}$ Ed., Chapman \& Hall Ltd., London, 335 pp.

Michael, G. L.; Joyce, P. N.; Weston, F. M. and Clement, Z. C. (2008). Effect of seed collection times and pretreatment methods on germination of Terminalea sericea Burch. Ex DC. African J. Biotech., 7 (16): 2840-2846.

Mostafazadeh, B.; Khoshravesh, M.; Mousavi, S. F. and Kiani, A. R. (2012). Effects of magnetized water on soil chemical components underneath trickle irrigation. J. Irrig. Drain. Ing., 138 (12): 10751081.

Moustafa, H. E. B.; Abdel-Fattah, Gehan, H. and Shahin, S. M. (2017). Germination of Moringa oleifera Lam. seeds under salinity conditions in the presence of magnetic iron. J. Biol. Chem. \& Environ. Sci., 12 (3): 551-566.

Naik, S. G.; Vasundhara, M.; Mangesh, P. G.; Shivayogappa, G. and Babu, P. (2010). Studies on the propagation of Terminalia arjuna Roxb. through seeds. Biomed; 5: 104-111.
Odetola, J. A. (1987). Studies on seed dormancy, viability and germination in ornamental palms. Principles, 31 (1): 24-30.

Orwa, C.; Mutua, A.; Kindt, R.; Jamnadass, R. and Simons, A. (2009). Agroforestree database: A tree reference and selection guid, version 4.0, p.1-5.

Pandey, S. M.; Jaiswal, U. and Jaiswal, V. S. (2006). Shoot initiation and multiplication from a mature tree of Terminalia arjuna Roxb. S.N. vitro cell Dev. Biol. Plant, 42: 389-393.

Santos, A. R. F.; Silva-Mann, R.; Ferreira, R. A. and Brito, A. de S. (2011). Water pre-hydration as priming for Moringa oliefera Lam. seeds under salt stress. Tropical and Subtropical Agroecosystems, 14: 201-207.

SAS, Institute. (2009). SAS/STAT User's Guides Statistics. Vers. 6.04, $4^{\text {th }}$ Ed., SAS. Institute Inc. Cary, N.C., USA.

Selvaraju, P. and Selvaraj, J. A. (1994). Effect of presowing treatments on germination and vigour of seed in marigold (Tagetes erecta L.). Madras Agric. J., 81 (9): 469-497.

Steel, R. G. D. and Torrie, J. H. (1980). Principles and Procedures of Statistics. McGrow Hill Book Co., Inc., New York, p: 377-400.

Sultana, B.; Anwar, F. and Przybylski, R. (2007). Antioxidant activity of phenolic compounds present in barks of Azadirachta indica,Terminalia arjuna, Acacia nilotica and Eugenia jambolana Lam. trees. Food Chem., 104: 1106-1114.

Tomar, O. S. and Gupta, R. K. (1985). Performance of some forest tree species in saline soils under shallow and saline water-table conditions. Plant and Soil, 87: 329-335.

\section{إنبات بذور شجرة اللوز الهندي (Terminalia arjuna Roxb.) المتأثرة بملوحة التربة في وجود أو غياب الحديد الممغنط

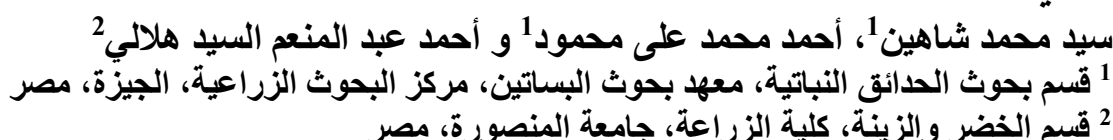

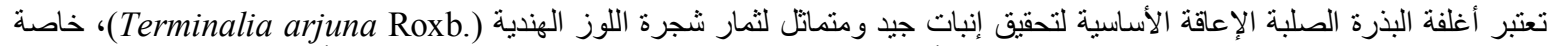

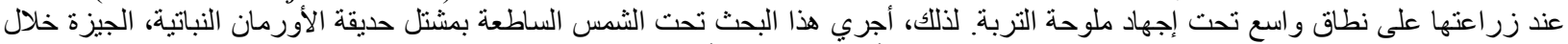

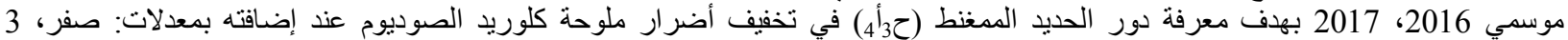

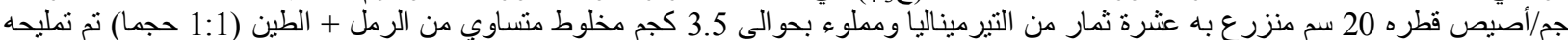

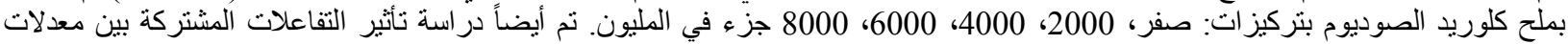

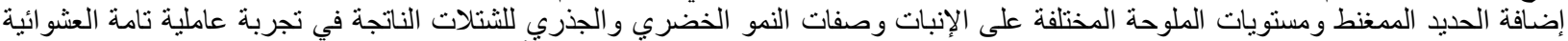

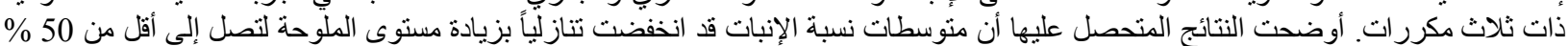

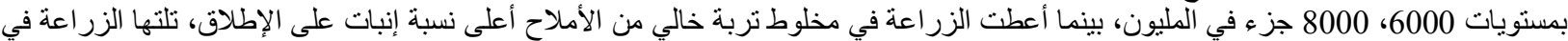

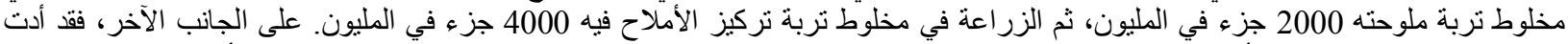

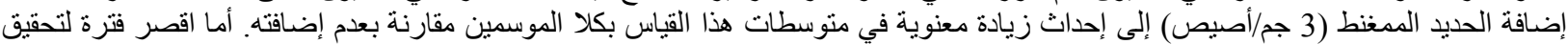

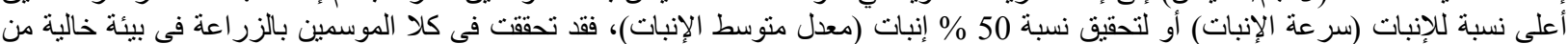

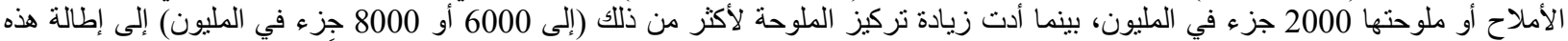

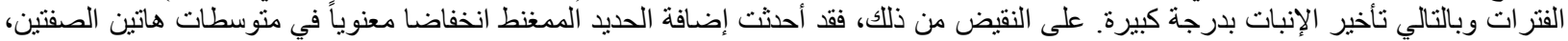

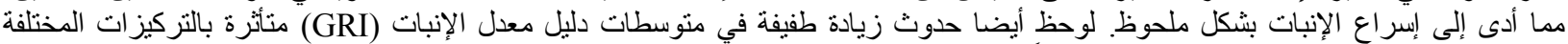

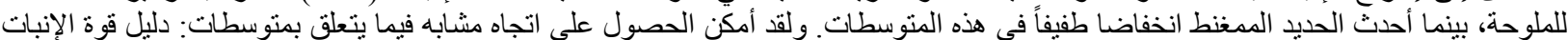

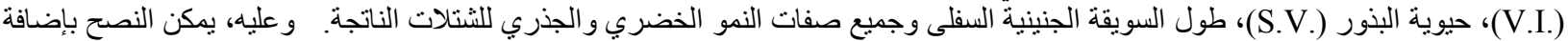

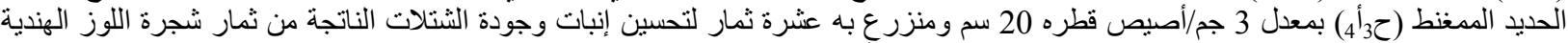
عند زر اعتها في تربة منخفضة أو منوسطة الملوحة. 